\title{
Deletion of NF-kB p50 alters murine glioblastoma tumor-associated macrophage polarization, reduces tumor growth and prolongs survival
}

\author{
Theresa Barberi", Allison Martin, Sarah Harris-Bookman, Michael Lim, Alan D Friedman \\ From 30th Annual Meeting and Associated Programs of the Society for Immunotherapy of Cancer (SITC 2015) \\ National Harbor, MD, USA. 4-8 November 2015
}

Glioblastoma multiforme (GBM) is a uniformly fatal brain tumor. The GBM microenvironment includes abundant tumor-associated macrophages (TAMs) that predominantly assume a pro-tumor "M2" phenotype rather than a pro-inflammatory "M1" phenotype. TAMs suppress $\mathrm{T}$ cell activation, produce VEGF, secrete proliferative factors, and encourage tumor invasion and metastasis. The inhibitory p50 subunit of the NF-kB transcription factor exhibits markedly increased nuclear expression in TAMs and M2-polarized macrophages [1], and p50 knockdown or deletion suppresses expression of M2-associated factors [1-3]. We hypothesize that absence of TAM p50 will convert TAMs to a proinflammatory M1 phenotype that will reduce tumor growth and prolong survival.

The murine glioma cell line GL261-Luc was intracranially implanted into wild-type and p50(-/-) mice. Tumors grew 6-fold slower in p50(-/-) compared with wild-type mice, and p50(-/-) mice exhibited significantly increased survival. RT-qPCR analysis of CD11b+ myeloid cells isolated from the brains of tumor-bearing mice revealed decreased M2 marker expression and increased M1 marker expression in the absence of NF-kB p50. Evaluation of tumor-infiltrating $\mathrm{T}$ cells indicated that $\mathrm{p} 50$ $(-/-)$ mice possess decreased Treg cells, and that more p50(-/-) CD4 T cells induce IFNg expression after PMA/ Ionomycin stimulation than wild-type CD4 T cells. When M2-polarized p50(-/-) bone marrow-derived macrophages (BMM) are co-cultured in vitro with wildtype $\mathrm{T}$ cells, they do not suppress $\mathrm{T}$ cell proliferation to the same extent as wild-type BMM. These data suggest that NF-kB p50 is an important modulator of the suppressive TAM phenotype in GBM and that deletion of

Johns Hopkins University School of Medicine, Baltimore, MD, USA the gene encoding $\mathrm{p} 50$ promotes conversion to a proinflammatory phenotype that is less tumor-permissive. We anticipate that targeting p50 in combination with immune checkpoint inhibition might prove synergistic in facilitating anti-tumor immunity and tumor regression.

Published: 4 November 2015

\section{doi:10.1186/2051-1426-3-S2-P395}

Cite this article as: Barberi et al:: Deletion of NF-kB p50 alters murine glioblastoma tumor-associated macrophage polarization, reduces tumor growth and prolongs survival. Journal for ImmunoTherapy of Cancer 2015 3(Suppl 2):P395.
Submit your next manuscript to BioMed Central and take full advantage of:

- Convenient online submission

- Thorough peer review

- No space constraints or color figure charges

- Immediate publication on acceptance

- Inclusion in PubMed, CAS, Scopus and Google Scholar

- Research which is freely available for redistribution
() Biomed Central 